\title{
Archaeopyle variability in Early Cretaceous dinocysts of the partiform gonyaulacoid genus Druggidium Habib
}

\author{
IAN C. HARDING \\ Department of Earth Sciences, University of Cambridge, Downing St., Cambridge CB2 3EQ
}

\begin{abstract}
Scanning electron microscope (S.E.M.) observation techniques have enabled paratabulation formulae to be elucidated (in both Kofoidian and Taylor-Evitt notation) for the partiform gonyaulacoid dinocyst genus Druggidium Habib. Archaeopyle variability within the species of this genus is highlighted, further emphasising the uncertainties concerning the taxonomic significance of archaeopyle type. The genus Druggidium is therefore emended, as is the species $D$. jubatum Duxbury. One new species, $D$. augustum, is described.
\end{abstract}

\section{INTRODUCTION}

The Early Cretaceous dinocyst genus Druggidium was erected by Habib (1973) for three species of small proximate dinocysts present in core samples collected by the Deep Sea Drilling Project from Site 105 in the western North Atlantic. The three species described were $D$. apicopaucium (the type species), $D$. deflandrei and $D$. rhabdoreticulatum, ranging from the Berriasian to the Hauterivian. Subsequently, Davey (1974) illustrated a further species of this genus from the Barremian of Speeton, Yorkshire. This form was described by Duxbury (1980) as $D$. jubatum on examination of further material from Speeton. Lejeune-Carpentier \& Sarjeant (1983) transferred two species from Phanerodinium into the genus Druggidium as $D$. fourmarierii and $D$. laeve. However, the attribution of these species is questionable for reasons that will be discussed later. A new species referable to Druggidium has recently been discovered and is described herein.

All species of this genus exhibit paratabulation features. The paratabulation formula, as given by Habib (1973, p. 49) was $3^{\prime}-4^{\prime}, \mathrm{Oa}, 6^{\prime \prime}, 6 \mathrm{c}, 6^{\prime \prime \prime}, 1 \mathrm{p}, 1^{\prime \prime \prime}$. This has since been modified to $\mathrm{pr}, 4^{\prime}, 4 \mathrm{a}, 7^{\prime}, 7 \mathrm{c}, 6^{\prime \prime \prime}$, 1p, 1"", 2s (Habib in Habib \& Drugg, 1983). This revision of the epicystal paraplating was based on observations of paratype material using the S.E.M.

The nature of the archaeopyle in Druggidium was defined as $2 \mathrm{P}$, (originally paraplates $2^{\prime \prime}$ and $3^{\prime \prime}$ were believed to be involved, now $3^{\prime \prime}$ and $4^{\prime \prime}$ have been shown to be the paraplates concerned - see Habib \& Drugg, 1983, p. 634). However, studies conducted on Western European material from the Boreal Province indicate that the formation of a $2 \mathrm{P}$ archaeopyle, with the opercular pieces adherent to the paracingulum is only one of a range of archaeopyle types found within the genus. Evitt (1985, p. 145) lists several genera whose individual species have been found to exhibit archaeopyle variability. Mehrotra \& Sarjeant (1984) reported archaeopyle variability within a single species, Dingodinium cerviculum.

Throughout this paper, Kofoidian nomenclature has been employed, Taylor-Evitt equivalents being given in square brackets [ ] where applicable.

\section{STRATIGRAPHIC CORRELATION OF SAMPLES}

Samples examined in this study came from three localities:

1. The Speeton Clay series of Speeton, E. Yorkshire (see Rawson \& Mutterlose, 1984).

2. The Otto-Gott brickpit, N.E. of Sarstedt, near Hannover, West Germany (see Mutterlose, 1984).

3. The B.G.S. Hunstanton borehole, Norfolk (samples made available to Dr. N. F. Hughes by R. W. Gallois: see Gallois, 1972).

Specimens of Druggidium have been encountered in samples from all three localities, accounting for up to $8 \%$ of the dinocyst floras. The species identified are $D$. jubatum, D. augustum sp. nov. and D. cf. apicopaucicum (rare). Peak abundances of this genus are found within the Blätterton facies (Bed 100 at Gott). This facies comprises black, finely laminated claystones which have been reliably correlated using cephalopods with the LB1 beds of the Speeton Clay succession (Rawson \& Mutterlose, 1983). It was from the top of the LB1 beds that Duxbury (1980) originally described D. jubatum.

The correlation with the "Snettisham Clay" of the Hunstanton borehole is less well defined and is the subject of current research but preliminary work indicates that the clays between $130 \mathrm{ft}$ and $150 \mathrm{ft}$ may correlate with the Blätterton. 


\section{ARCHAEOPYLE CHARACTER}

Previous interpretations of archaeopyle type in Druggidium have indicated a two-paraplate precingular archaeopyle, a compound biplacoid operculum often remaining adherent to the cingular paraplate series (Habib, 1973; Habib \& Drugg, 1983).

When Davey (1974, p. 50) described Druggidium sp., he stated that the "precingular archaeopyle is low and wide and appears to be formed by the loss of one precingular plate". The light micrographs of this dinocyst (op. cit., pl. 2, figs. 7-9) indicate a twoparaplate archaeopyle. However, the electron micrograph of another specimen (op. cit., pl. 3, fig. 3) displays a single paraplate archaeopyle, both specimens having lost their operculae. Duxbury (1980, p. 117), describing $D$. jubatum stated only that the archaeopyle was "precingular, mid-dorsal in position". One of his illustrations (op. cit., pl. 3, fig. 4), appears to show a 2P archaeopyle, $4^{\prime \prime}$ having been lost and $3^{\prime \prime}$ remaining attached apically.

The present examination of species of Druggidium has shown that only a relatively low percentage of cysts of this genus exhibit an excystment structure. Of specimens of $D$. jubatum, 32\% displayed archaeopyles, the figure being $27 \%$ for $D$. augustum sp. nov. The few specimens of $D$. cf. apicopaucicum studied yielded no information on archaeopyle type. Despite this, the relatively high abundance of the first two species has enabled a significant number of excysted specimens to be examined.

\section{Druggidium jubatum}

Three types of archaeopyle have been found in this species:-

(i) Type $\mathrm{P}$

- involving the loss of paraplate $4^{\prime \prime}[4 \mathrm{u}]$ as a free monoplacoid

(ii) Type $2 \mathrm{P}$ operculum (see Pl. 1, fig. 3).

- compound biplacoid operculum: paraplates $3^{\prime \prime}[4 \mathrm{i}]$ and $4^{\prime \prime}[4 \mathrm{u}]$ involved. $3^{\prime \prime}$ apically adherent, 4" free (see Pl. 1, fig. 6).

(iii) Type $2 \mathrm{P} \quad$ - operculum free, compound biplacoid type involving $3^{\prime \prime}[4 \mathrm{i}]$ and $4 "[4 \mathrm{u}]$ see (Pl. 1, fig. 9).

Of these types, the second one is by far the most commonly observed (60\% of specimens). The third type (although it is the type described in the generic diagnosis) is the least common of the three $(15 \%)$ and may be a modification of the second type caused by processing techniques.

\section{Druggidium augustum sp. nov.}

This species displayed two different types of archaeopyle:- (i) Type (AI)a2Pa - combination archaeopyle: a simple polyplacoid opercular piece (comprising apical and intercalary paraplate series) adnate via a sulcal "tongue". In addition to this, accessory archaeopyle sutures are developed involving paraplates $3^{\prime \prime}[4 i]$ and $4 "[4 u]$, these remaining adnate adcingularly (see Pl. 2, figs. 3, 6, 9).

(ii) Type (AI) $2 \mathrm{~Pa}$ - as for the preceeding type but involving the loss of the apical and intercalary series as a free simple polyplacoid opercular piece.

In this instance, the first type is the most frequently encountered $(80 \%)$, the second type may again be a modification of the first due to processing techniques. Druggidium cf. apicopaucicum may also develop an (AI)a2Pa archaeopyle (see pl. 3, figs. 1-2 of Habib \& Drugg, 1983).

\section{SYSTEMATIC DESCRIPTIONS}

Division Pyrrophyta Pascher, 1914

Class Dinophyceae Fritsch, 1929

Genus Druggidium Habib, 1973 emend.

Partially emended diagnosis. The genus is emended to incorporate the paratabulation formula as revised by Habib (Habib \& Drugg, 1983) for D. apicopaucicum and observed by the present author on $D$. jubatum and D. augustum sp. nov. The formula is - pr, $4^{\prime}, 4 \mathrm{a}, 7^{\prime \prime}, 7 \mathrm{c}$, $6^{\prime \prime \prime}, 1 \mathrm{p}, 1^{\prime \prime \prime}, 2 \mathrm{~s}$ (in Kofoidian notation: for Taylor-Evitt comparisons see Figs. 1-3). The emendation also stresses the variable nature of the archaeopyle structure within the genus. The following archaeopyle types have so far been observed within the genus:--

(i) Type $\mathbf{P}$

(ii) Type $2 \mathrm{P}$

- compound biplacoid operculum: both pieces adherent adcingularly.

(iii) Type $2 \mathrm{P}$

- compound biplacoid operculum: $3^{\prime \prime}[4 i]$ adapically adherent, $4 "[4 \mathrm{u}]$ free.

(iv) Type $2 \mathrm{P}$

- compound biplacoid operculum: both pieces free.

(v) Type (AI)a2Pa

(vi) Type (AI) $2 \mathrm{~Pa}$

Remarks. Evidence from S.E.M. observations upon species of this genus reveal the presence of distinct anterior intercalaries associated with seven precingular paraplates. Thus, the genus should be placed in the Microdinium complex of Gp-cysts rather than the 
Phanerodinium complex (Evitt, 1985, p. 215-6).

The transferals of Phanerodinium fourmarierii Lejeune-Carpentier and $P$. laeve Lejeune-Carpentier to Druggidium (Lejeune-Carpentier \& Sarjeant, 1983) are questionable. $P$. laeve is a species based on one very poorly known specimen. The diagnostic apical and ventral areas are not visible in the flint matrix and the specimen displays no archaeopyle. The paratabulation formula indicates no anterior intercalaries, a feature now known to characterise the genus. It is recommended that $P$. laeve is retained in Phanerodinium and the species name suppressed, being used to refer only to the holotype.

The characters displayed by Phanerodinium fourmarierii do not unequivocally argue for a transferral to Druggidium. The arrangement of the apical paraplates on the paratype is clearly dissimilar to that now known for the latter genus as it possesses only one anterior intercalary paraplate and a much reduced second precingular. The ventral paratabulation of this species is also poorly known, a posterior intercalary paraplate was "presumed but could not be confirmed" (LejeuneCarpentier \& Sarjeant, 1983, p. 3). Thus P. fourmarierii should be retained in Phanerodinium until more details of its paratabulation are known. In addition to the above differences, it is of importance to note that all of the positively identified species of Druggidium are restricted to the pre-Aptian Early Cretaceous whereas $P$. fourmarierii and $P$. laeve were described from the Senonian. The present state of knowledge indicates that this genus is of excellent stratigraphic value, the individual species being of restricted range and of moderate abundance.
Druggidium jubatum Duxbury, 1980 emend.

(Pl. 1, figs. 1-9; Figs. 1, 2)

\section{Emended diagnosis}

Shape: Ambitus rectangular, elongated anteroposteriorly, maximum cyst width across posterior paracingular parasutural crest. Cyst length unequally divided, being $2 / 3$ hypocyst, the remainder shared equally by the paracingulum and the epicyst. Little or no dorsoventral compression.

Phragma: Differentiated autophragm (Evitt, 1985, p. 64) in the manner of Aldorfia aldorfensis (see Gocht, 1975), giving an alveolar appearance to the paraplate cross-section (Pl. 1, fig. 8). Total phragmal thickness $1.0-1.5 \mu \mathrm{m}$. Autophragm outer surface perforate, pseudoreticulate. High parasutural crests developed on hypocyst up to $3 \mu \mathrm{m}$ high), much reduced on precingular paraplates to almost absent on the anterior intercalary and apical series.

Paratabulation: Pr, 4', 4a, 7", 7c, 6"', 1p, 1"'", 2s (Kofoidian notation. Taylor-Evitt plate equivalents as shown in Figs. 1,2). Paraplates $7 \mathrm{c}[1 \mathrm{i}]$ and as [ai] narrow and elongate.

Archaeopyle: Variable. Types i., iii. or iv. as listed in the emended generic diagnosis.

Paracingulum: Strongly developed, delineated by high parasutural crest posteriorly, crest more subdued anteriorly.

Parasulcus: Prominent flagellar scar. Large spatulate sulcal paraplate $s[Z]$, narrows rapidly towards paracingulum. Paraplates rs[Ii] and $\mathrm{ls}[\mathrm{Im}]$ not differentiated.
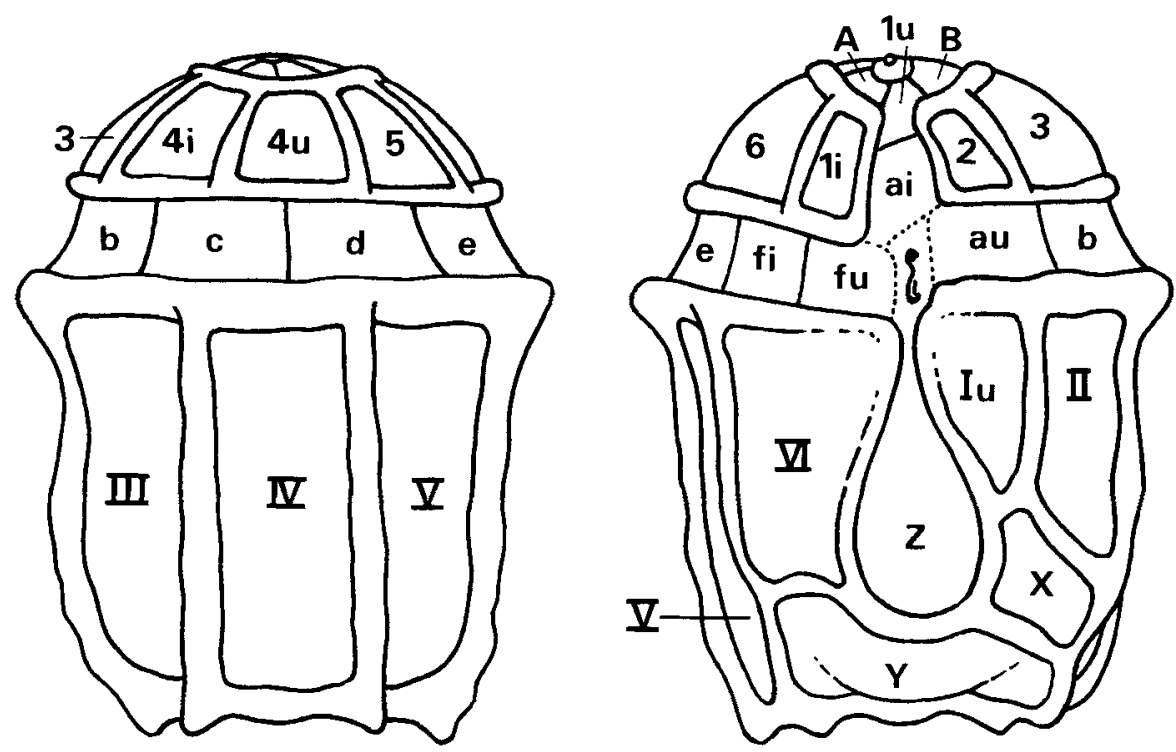

Fig. 1. Generalised reconstruction of the paratabulation of Druggidium jubatum (Taylor-Evitt notation). Left: dorsal view; right: ventral view. 


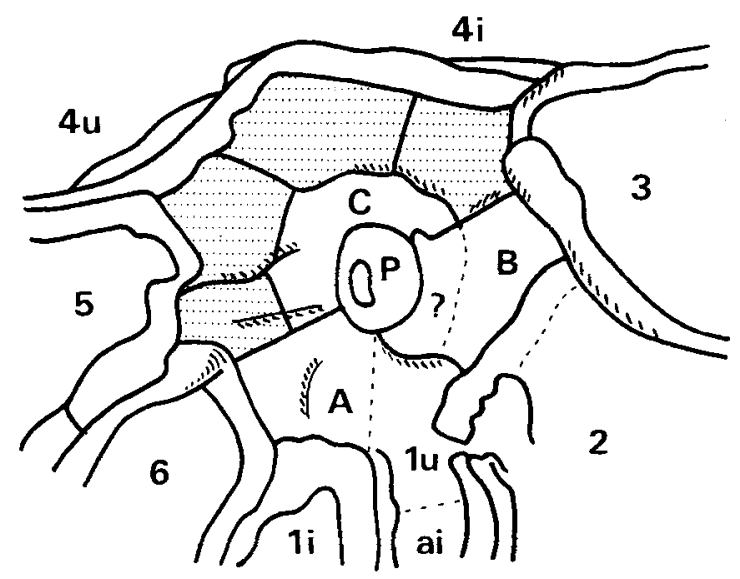

Fig. 2. Interpretation of apical and anterior intercalary paratabulation in Druggidium jubatum, see Pl. 1, fig. 5 (Taylor-Evitt notation - Kofoidian anterior intercalary paraplates stippled).

Dimensions. Length (40) 29.8 (24) $\mu \mathrm{m}$. Width (29) 24.6 (21) $\mu \mathrm{m}$. Width:length ratio (1.08) $0.83(0.67) .50$ specimens measured.

Remarks. This species is emended after study of topotype material, to detail the complete paratabulation (not originally stated in Duxbury, 1980), wall structure and archaeopyle variability.
Druggidium augustum sp. nov.

(Pl. 2, figs. 1-9; Fig. 3)

Derivation of name. Latin augustus, meaning sacred. In reference to provenance from Otto-Gott brickpit, Gott being the German for God.

Diagnosis.

Shape: Ambitus subcircular to ovoid, elongated anteroposteriorly. Greatest width just posterior to the paracingulum. Cyst length unequally divided: hypocyst $2 / 3$ of total, the very wide paracingulum and the epicyst sharing the remaining length equally. Slight dorsoventral compression (specimens flattened due to postmortem compression within the rock matrix as they show no consistent preferred orientation).

Phragma: Autophragm only, extremely thin (0.1$0.3 \mu \mathrm{m}$ thick), strengthened by continuous parasutural ridges $(0.4-0.6 \mu \mathrm{m}$ wide). Sculpture variable, granular. Granulae may be small and discrete or become fused and merge with the parasutural ridges (especially on the epicyst) and obscure tabulation. Indications of plate-overlap sometimes evident. Circular "ringed pits" may be present on some paraplates (Pl. 2, fig. 4). Paratabulation: As revised for the genus. Paraplate $4^{\prime \prime}[\mathrm{A}]$ reduced in length, $7 "[1 \mathrm{i}]$ no longer in contact with 6c[fi] (see Evitt, 1985, fig. 5. 18C). Epicystal paratabulation often obscured by the sculpture.

Archaeopyle: Variable. Types v. or vi. as listed in the emended generic diagnosis.

\section{Explanation of Plate 1}

Druggidium jubatum (Duxbury, 1980) emend.

All reference numbers refer to positions on Cambridge Geology Grid Mk. III

Fig. 1. Ref. 340823, Stub IC 316, Prep. CH 104, Sample Gott 100/1/83. Ventral view $(\times 1600)$.

Fig. 2. Ref. 228874, Stub IC 320, Prep. CH 189, Sample Gott 100/1/83. Ventral view $(\times 1600)$.

Fig. 3. Ref. 291834, Stub IC 323, Prep. CH107, Sample Gott c98/1. Showing single plate (4"[4u]) precigular archaeopyle $(\times 1600)$.

Fig. 4. Ref. 293818, Stub IC 300, Prep. CH100, Sample Gott 100/8/83. Antapical view showing 1"'[Y], parasulcus to bottom $(\times 1600)$.

Fig. 5. Ref. 365773, data as for Fig. 3. Apical view showing paratabulation (see Fig. 2 in text) $(\times 7000)$.

Fig. 6. Ref. 232798, Stub IC 282, Prep. CH 097, Sample Gott 100/5/83. 2P archaeopyle, 3"[4i] adherent apically $(\times 1600)$.

Fig. 7. Ref. 391832, data as for Fig. 3. Detail of flagellar scar and constriction of anterior part of spatulate parasulcus $(\times 7000)$.

Fig. 8. Ref. 233746, data as for Fig. 4. Cross section of cyst wall showing fibrous connecting struts $(\times 1400)$.

Fig. 9. Ref. 306775, Stub GD 263, Prep. X229, Sample Speeton CS 43. Showing 2P archaeopyle, opercular pieces free $(\times 1600)$. 

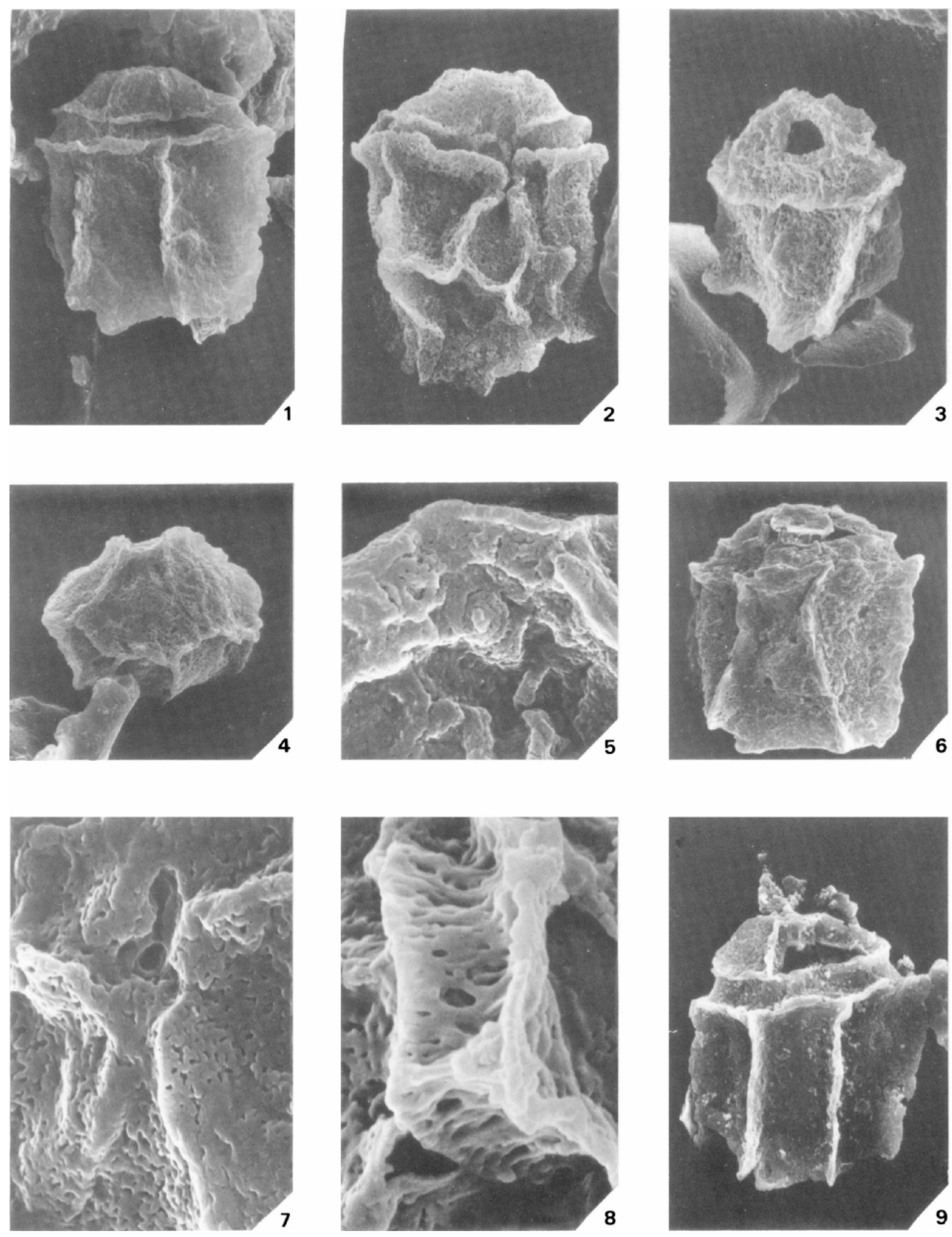
Paracingulum: Well developed, very broad, no indentation seen in ambital view.

Parasulcus: Large spatulate sulcal paraplate $s[Z]$, margins convex and narrowing gradually anteriorly. Paraplate rs[Ii] developed but not $1 \mathrm{~s}[\mathrm{Im}]$. Prominent flagellar scar.

Holotype. Pl. 2, fig. 1.

Locality and horizon. Otto-Gott brickpit, N.E. of Sarstedt, near Hannover, West Germany, $1.5 \mathrm{~m}$ above the base of Bed 100 .

Dimensions. Length (38) 31.6 (26) $\mu \mathrm{m}$. Width (35) 28
(24) $\mu \mathrm{m}$. Width:length ratio (1.10) $0.90(0.73) .50$ specimens measured.

Remarks. This species can be distinguished from the other members of the genus by the characteristic sculpture of its thin autophragm. It differs from Microdinium (Cookson \& Eisenack) Stover \& Evitt in mode of paratabulation and archaeopyle type.

Druggidium augustum sp. nov. has been found in samples of latest Hauterivian to latest Early Barremian at Gott (Harding \& Mutterlose, in press), Speeton and Hunstanton.
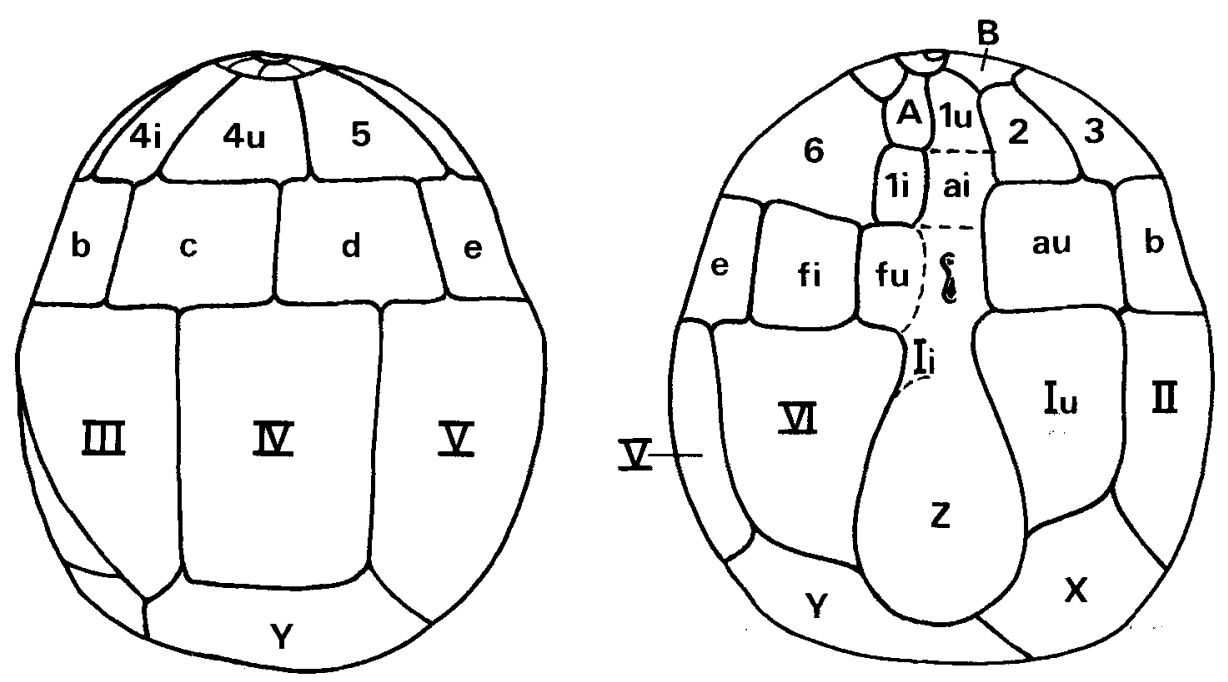

Fig. 3. Generalised reconstruction of the paratabulation of Druggidium augustum sp. nov. (Taylor-Evitt notation). Left: dorsal view; right: ventral view.

\section{Explanation of Plate 2}

Druggidium angustum sp. nov.

All reference numbers refer to positions on Cambridge Geology Grid Mk. III

Figs. 1, 2. Holotype, Ref. 305774, Stub IC 297, Prep. CH 100, Sample Gott 100/8/83: fig. 1, ventral view $(\times 1600)$; fig. 2, detail of sculpture and parasutures $(\times 7000)$.

Fig. 3. Ref. 342788, Stub IC 291, Prep. CH 095, Sample Gott 100/3/83. Ventral view of specimen with attached apical operculum.

Fig. 4. Ref. 331787, Stub IC 289, data as for fig. 3. Dorsal view of large specimen with apical rupture, showing reduced paraplate 4 "' [IV] $(\times 1600)$.

Fig. 5. Ref. 288817, data as for fig. 4. Dorsal view $(\times 1600)$.

Fig. 6. Ref. 271819, data as for fig. 4. Dorsal view of specimen with attached apical operculum $(\times 1600)$

Figs. 7, 8. Ref. 328709, data as for fig. 4; fig. 7, ventral view, showing large spatulate sulcus $(\times 1600)$; fig. 8 , detail, showing flagellar scar $(\times 3500)$.

Fig. 9. Ref. 418791, data as for fig. 3. Ventral view of specimen with attached operculum $(\times 1600)$. 

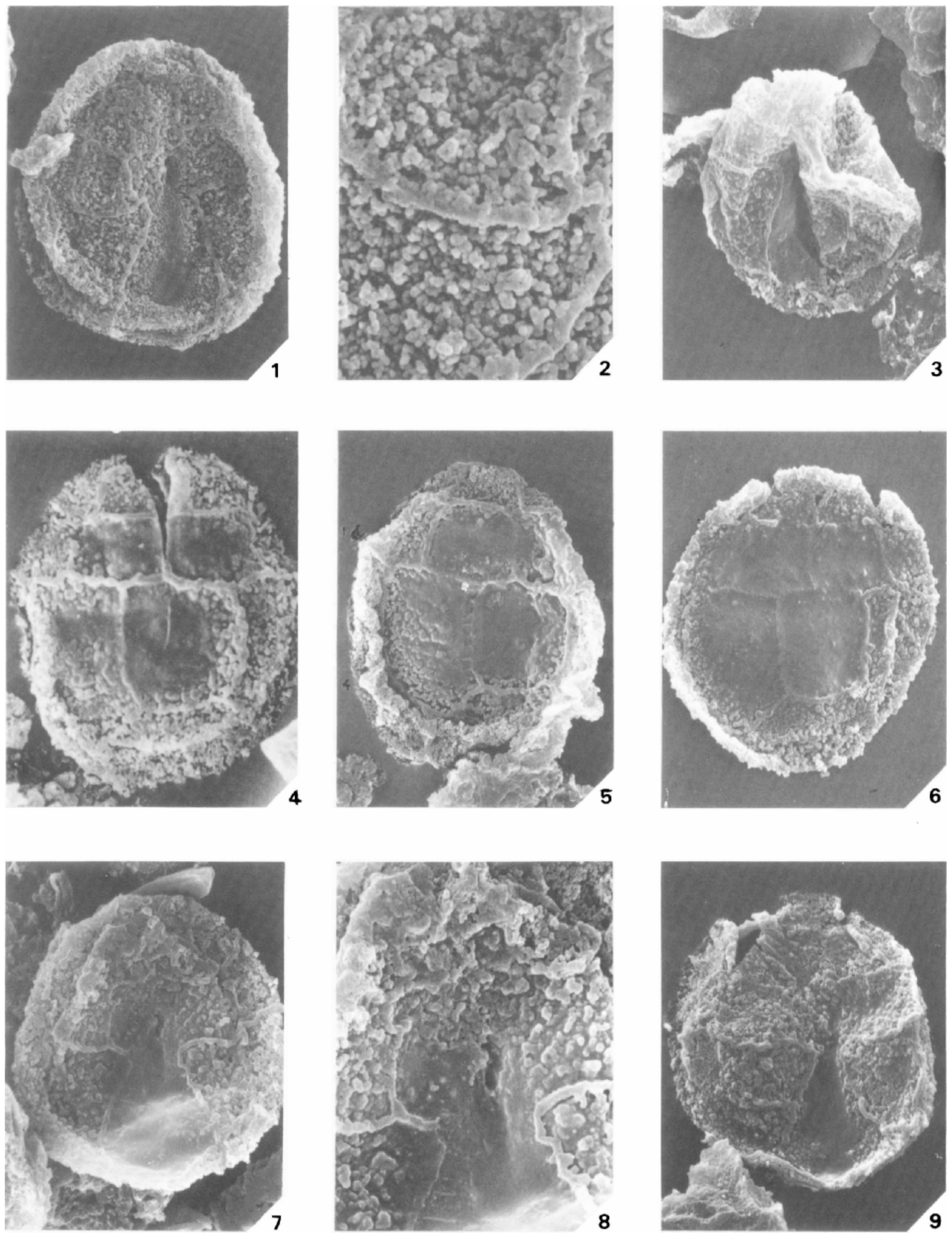


\section{Druggidium sp.}

(Pl. 3, figs, 1-8)

Dimensions. Length (25) $20.5(16) \mu \mathrm{m}$. Width (23) 17.9 (13) $\mu \mathrm{m}$. Width:length ratio (1.05) $0.81(0.71)$. C.I. (39) 31 (21). 26 specimens measured.

Remarks. This species bears some resemblance to Druggidium deflandrei (Millioud) Habib. The electron micrograph of this species illustrated by Habib (1973, pl. 3, fig. 4) shows an alveolate surface sculpture very like that of $D$. sp. However, although the dimensions of the present specimens agree with those determined from the electron micrograph, they do not agree with the dimensions stated in the species descriptions or with those determinable from the light micrographs (the magnification of which seems to be erroneous). The present specimens compared with the description of $D$. deflandrei are smaller, less anteroposteriorly elongated and have a higher C.I. (cingulum index).

The archaeopyle seems to be a $2 \mathrm{P}$ type with the paraplates involved $\left(3^{\prime \prime}[4 i]\right.$ and $\left.4^{\prime \prime}[4 u]\right)$ sometimes remaining adherent adcingularly. However the adjacent precingular paraplates $\left(2 "[3]\right.$ and $\left.5^{\prime \prime}[5]\right)$ often appear torn and the remaining epicystal paraplates collapse inwards making interpretation difficult. Tabulation is of the $D$. jubatum type (i.e. $7^{\prime \prime}[1 \mathrm{i}]$ somewhat reduced but still in contact with 6c[fi]- Evitt, 1985, fig. 5. 18B).

This species is a good marker for the latest Hauterivian to very earliest Barremian at Gott and Speeton.

\section{Explanation of Plate 3}

All reference numbers refer to positions on Cambridge Geology Grid Mk. III

Figs. 1-3. Druggidium augustum sp. nov.

Fig. 1. Ref. 276750, Stub IC 297, Prep. CH 100, Sample Gott 100/8/83. Detail of dorsal epicyst showing four Kofoidian intercalary paraplates: $\mathrm{pr}[\mathrm{P}], 2^{\prime}[\mathrm{B}]$ and $3^{\prime}[\mathrm{C}]$ can also be made out $(\times 3500)$.

Fig. 2. Ref. 268803, Stub IC 374, Prep. CH 031, Sample Speeton ICH 003 . Dorsal view with (AI)a2Pa archaeopyle $(\times 1600)$.

Fig. 3. Ref. 274811, data as for fig. 2. Ventral view $(\times 1600)$.

Figs. 4-14. Druggidium sp.

Fig. 4. Ref. 317866, Stub IC 339, Prep. Z 239, Sample Gott c74/1 Dorsal view $(\times 1600)$.

Fig. 5. Ref. 317884 , data as for fig. 10. Dorsal view of slightly distorted specimen with well developed alveolar sculpture $(\times 1600)$.

Fig. 6. Ref. 375788, Stub IC 333, Prep. Z 225, Sample Gott 61/1/79. Right lateral view, archaeopyle to top left $(\times 1600)$.

Fig. 7. Ref. 322826, data as for fig. 6. Detail of epicyst showing apical and intercalary series barely $3 \mu \mathrm{m}$ across, pr[P] arrowed $(\times 14000)$.

Fig. 8. Ref. 261842, Stub IC 320, Prep. CH189, Sample Gott 100/1/83. Ventral view showing spatulate sulcus and slightly reduced $7^{\prime \prime}[1 \mathrm{i}](\times 1600)$.

Fig. 9. Ref. 247776, Stub IC 338, rest of data as for fig. 4. Dorsal view showing displaced $3 "[4 \mathrm{i}]$ and $4 "[4 \mathrm{u}](\times 1600)$.

Fig. 10. Ref. 234763, Stub IC 330, Prep. Z 224, Sample Gott 56/1/79. Dorsal view showing ?2P archaeopyle $(\times 1600)$.

Fig. 11. Ref. 312882, Stub IC 328, Prep. Z 223, Sample Gott 50/1/79. Left lateral view, archaeopyle to top right $(\times 1600)$.

Fig. 12. Ref. 313718, Stub IC 323, Prep. CH 107, Sample Gott c98/1. Left lateral view, archaeopyle to top right $2 "[3]$ torn towards contact with $3^{\prime \prime}[4 i](\times 1600)$.

Fig. 13. Ref. 316886, Stub IC 335, Prep. Z 226, Sample Gott 67/1/79. Ventral view showing characteristic epicystal collapse $(\times 1600)$.

Fig. 14. Ref. 226816, Stub Experimental Y, Prep. Z 227, Sample Gott 71/1/79. Left lateral view $(\times 1600)$.

Fig. 15. D. cf. apicopaucicum. Ref. 319732, Stub IC 338, rest of data as for fig. 4. Ventral view showing large 1"'[Y] and relatively small spatulate $s^{\prime \prime}[Z]$. Note also flagellar scar $(\times 1600)$. 

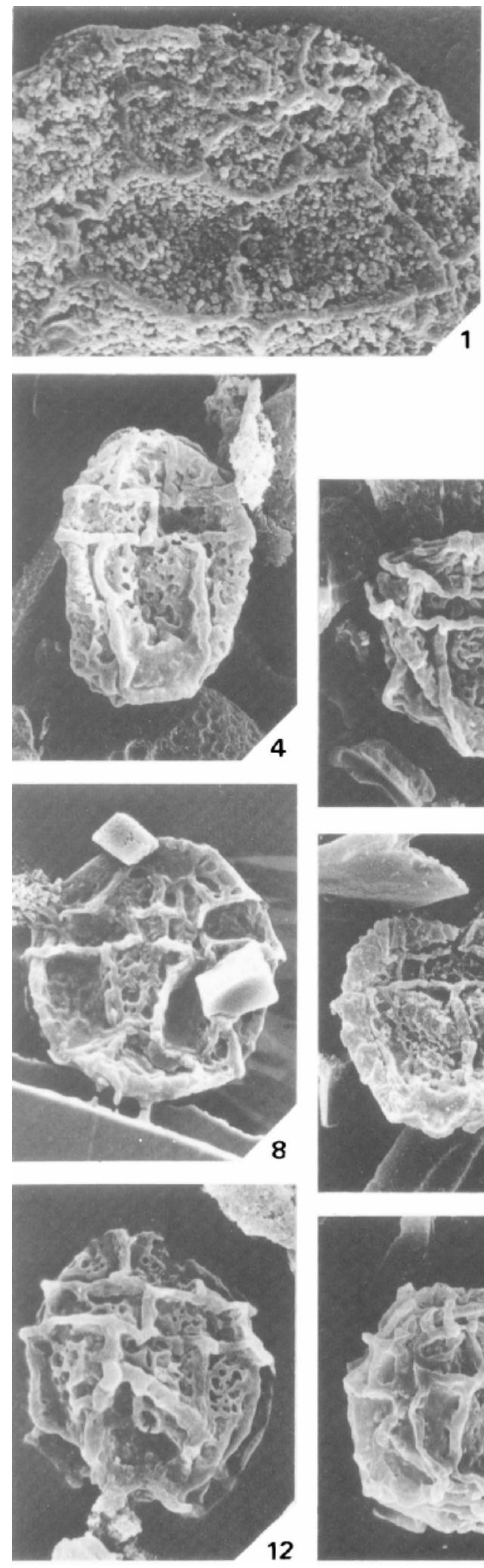
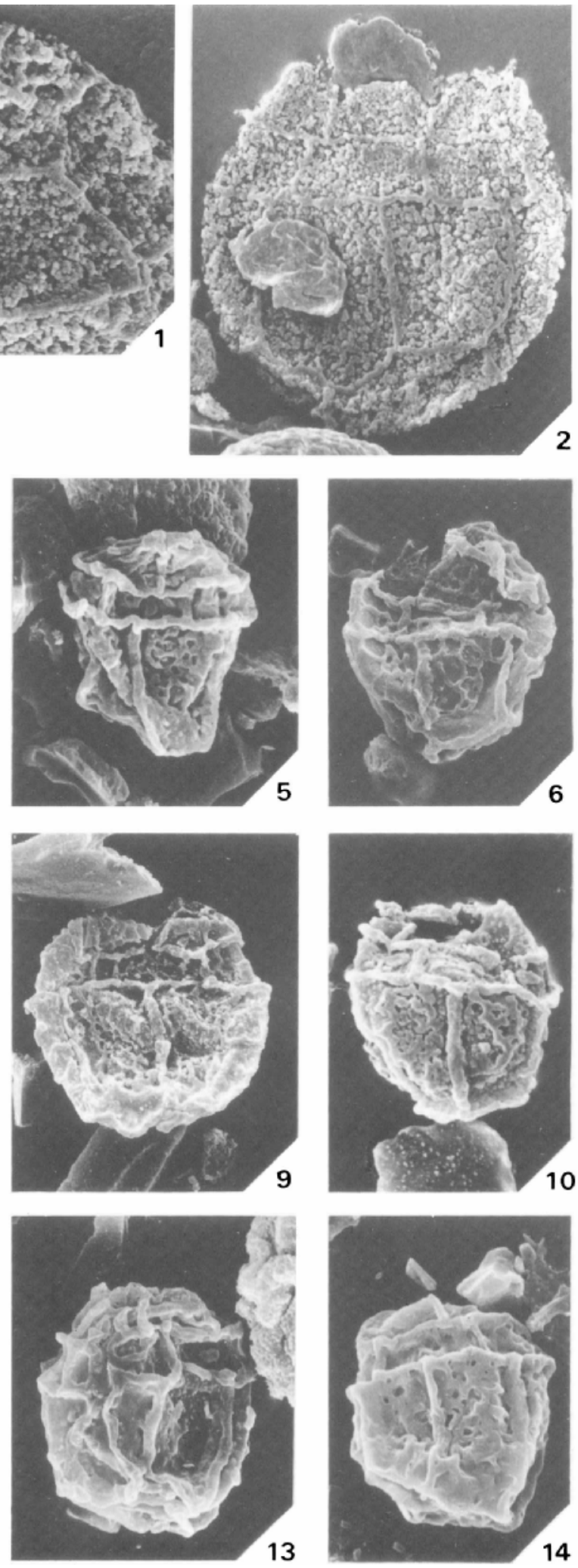
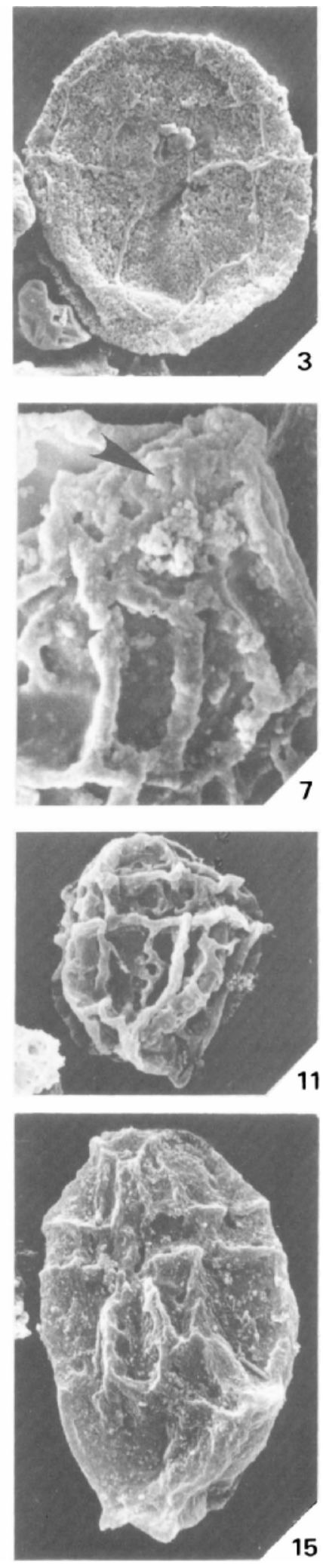


\section{CONCLUSIONS}

The value of S.E.M. observation in dinocyst taxonomy is well illustrated in this study. This is of special significance when interpreting such details as the eipcystal paratabulation of certain partiform gonyaulacoid dinocysts: such features as the apical and anterior intercalary paraplates would be beyond the resolution of the light microscope.

Druggidium clearly falls into the Microdinium complex of Gp-cysts, with its four anterior intercalaries and seven precingulars (of which 7"[1i] may be much reduced in size in some species). The intraspecific variability of archaeopyle type shows this character to be of little taxonomic value, whereas accurately determined paratabulation features appear to be a much more reliable taxonomic criterion.

\section{ACKNOWLEDGEMENTS}

Thanks are extended to Prof. J. W. Neale and Dr. J. Mutterlose for assistance in the field; to Dr. N. F. Hughes for providing additional samples and invaluable help; Mr. D. T. Newling and Mr. R. W. Lee for the preparation of illustrations; Mrs. P. Hancock for the typescript. The author acknowledges a N.E.R.C. studentship GT4/82/GS/122.

Manuscript received June 1985

Revised manuscript accepted December 1985

\section{REFERENCES}

Davey, R. J. 1974. Dinoflagellate cysts from the Barremian of the Speeton Clay, England. Birbal Sahni Inst. of Paleobotany, Spec. Pub. 3, 41-75, 9 pls.

Duxbury, S. 1980. Barremian phytoplankton from Speeton, East Yorkshire. Palaeontographica, Stuttgart, Abt. B, 173, 107-146, 13 pls.

Evitt, W. R. 1985. Sporopollenin dinoflagellate cysts: their morphology and interpretation. A. A. S. P., 333 pp.

Gallois, R. W. 1972. In Ann. Report for I. G.S. for 1971, 116, London.

Gocht, H. 1970. Dinoflagellaten-Zysten aus dem Bathonium des Erdolfeldes Aldorf (NW-Deutschland). Palaeontographica, Stuttgart, Abt. B, 129, 125-165, 10 pls.

Habib, D. 1973. Taxonomy, morphology and suggested phylogeny of the dinoflagellate genus Druggidium. Geoscience and Man, 7, 47-55, 3 pls.

Habib, D. \& Drugg, W. S. 1983. Dinoflagellate age of Middle Jurassic-Early Cretaceous sediments in the Blake-Bahama Basin. In Sheridan, R. E., Gradstein, F. M., et. al., Init. Repts. Deep Sea Drilling Project, 76, 623-628, 3 pls. Washington.

Harding, I. C. \& Mutterlose, J. In press. Phytoplankton from the anoxic sediments of the Barremian (Lower Cretaceous) of NW-Germany. Abh. Geol. Bundesanstalt, Vienna.

Lejeune-Carpentier, M. \& Sarjeant, W. A. S. 1983. Restudy of some smaller dinoflagellate cysts from the Upper Cretaceous of Belgium. Ann. Soc. Geol. Belgique, 106, $1-17,2$ pls.

Mehrotra, N. C. \& Sarjeant, W. A. S. 1984. Dingodinium, a dinoflagellate cyst genus exhibiting variation in archaeopyle character. Micropaleontology, 30, 295-305, pls.

Mutterlose, J. 1984. Die Unterkreide-Aufschlusse (ValanginAlb) im Raum Hannover-Braunschweig. Mitt. geol. Inst. Univ. Hannover, 24, $61 \mathrm{pp}$.

Rawson, P. F. \& Mutterlose, J. 1983. Stratigraphy of the Lower B and basal Cement Beds (Barremian) of the Speeton Clay, Yorkshire, England. Proc. Geol. Ass., 94, 133-146. 